\title{
Biodiversity-Ecosystem Functioning (BEF) approach to further understanding aquaculture-environment interactions with application to bivalve culture and benthic ecosystems
}

\author{
Lacoste Elise ${ }^{1,2,{ }^{*}}$, McKindsey Christopher W. ${ }^{3}$, Archambault Philippe ${ }^{4}$
}

1 UMR 241 EIO Université de Polynésie française Tahiti ,Polynésie française

2 MARBEC Univ Montpellier CNRS Ifremer IRD Sète, France

3 Maurice Lamontagne Institute Fisheries and Oceans Canada Mont-Joli ,Canada

${ }^{4}$ Département de biologie Faculté des Sciences et de Génie Université Laval Québec ,Canada

*Corresponding author : Elise Lacoste, email address : eliz.lacoste@gmail.com

\begin{abstract}
:
Coastal benthic ecosystems may be impacted by numerous human activities, including aquaculture, which continues to expand rapidly. Indeed, today aquaculture worldwide provides more biomass for human consumption than do wild fisheries. This rapid development raises questions about the interactions the practice has with the surrounding environment. In order to design strategies of sustainable ecosystem exploitation and marine spatial planning, a better understanding of coastal ecosystem functioning is needed so that tools to quantify impacts of human activities, including aquaculture, may be developed. To achieve this goal, some possible directions proposed are integrated studies leading to new concepts, model development based on these concepts and comparisons of various ecosystems on a global scale. This review draws on existing literature to (i) briefly summarize the major ecological interactions between off-bottom shellfish aquaculture and the environment, (ii) introduce research on the influence of benthic diversity on ecosystem functioning (BEF relationships) and (iii) propose a holistic approach to conduct aquaculture-environment studies using a BEF approach, highlighting the need for integrated studies that could offer insights and perspectives to guide future research efforts and improve the environmental management of aquaculture.
\end{abstract}

Keywords : aquaculture-environment interactions, benthic system, biodiversity, ecosystem functioning, shellfish. 


\section{Introduction}

35 Increasing human activities, including the pervasive effects of climate change, have dramatically

36 increased the rate of ecosystem disturbances with impacts on their structure and functioning (Gosling

37 2013). In turn, changes in functional ecosystem performance alter the way many ecosystem services

38 are delivered and thus the benefits humanity derives from nature. This observation has motivated

39 numerous studies to evaluate the consequences of disturbance on biological communities and

40 ecosystem functioning. As an example, Fig. 1 illustrates the modifications that arise from fisheries

41 impacting mechanisms underlying ecosystem functioning and fish stock availability as an ecosystem

42 service. Due to the complex food web functioning and the multiple interactions between species (e.g.

43 trophic cascades), the removal of species targeted by fisheries may have both direct and indirect

44 effects, negative or not on several other species (Pauly et al. 1998; Andersen \& Pedersen 2009). 


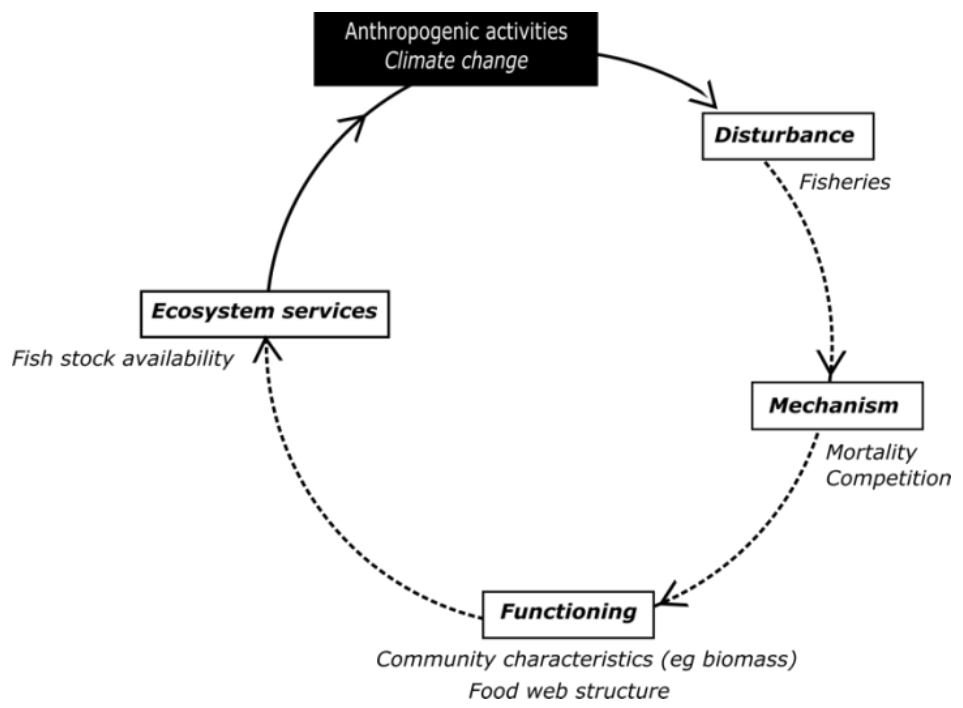

Figure 1. Cycle of ecosystem disturbance using the example of fisheries. Anthropogenic activities create disturbances that modify the underlying mechanisms of ecosystem functioning, thereby affecting ecosystem services that support anthropogenic activities.

Much research over the past few decades has focused on links between altered biodiversity (mainly species loss but also gains in the context of exotic species) and ecosystem functioning (e.g. Hooper et al. 2005; Cardinale et al. 2012; Harvey et al. 2013). Although most research in this field has concentrated on terrestrial systems, the number of manipulative experiments that assess the influence of benthic diversity on ecosystem functioning (BEF relationships) in marine systems has also recently increased rapidly (O’Connor \& Crowe 2005; Cardinale 2011; Solan et al. 2012; Gamfeldt et al. 2014; Séguin et al. 2014). These relationships have received much attention as they underpin many ecosystem services (Isbell et al. 2011; Balvanera et al. 2014; Cardinale et al. 2012). It is now generally accepted that higher biodiversity may increase ecosystem function efficiency, e.g. in terms of nutrient cycling (Cardinale et al. 2012; Gamfeldt et al. 2014; Piot et al. 2014), and/or resilience (Oliver et al. 2015). Moreover, there is general agreement on the importance of focusing on speciesspecific traits rather than species richness per se to describe links between biodiversity and metrics of ecosystem functioning (e.g. decomposition rates, nutrient uptake) (Mouillot et al. 2011; Gagic et 
al. 2015; Strong et al. 2015; Cernansky 2017).

Estuarine and coastal ecosystems deliver a wide range of ecosystem services while facing multiple natural and anthropogenic disturbances. An important example of such human disturbance in these ecosystems is aquaculture. This industry may profoundly alter ecosystem functioning (e.g. primary productivity), which in turn could constrain commercial species production (Ferriss et al. 2015; Price et al. 2015). With the continued development of aquaculture over the past few decades comes concerns about its environmental impacts and interactions with other activities in coastal areas (e.g. tourism, fisheries) (Edwards 2015; Bricker et al. 2016). Knowledge of aquaculture-environment interactions (AEI) is therefore essential for the sustainable development of the aquaculture industry and efficient marine spatial planning (Dempster \& Holmer 2009).

Unlike fish or shrimp farming, bivalve culture is considered to have low ecosystem impacts since animals are dependent on ambient supplies of plankton and organic particles for food (i.e. there is no addition of food to the natural environment). However, bivalve aquaculture accelerates nutrient dynamics due to bivalve excretion and mineralization of sedimented organic-rich bivalve biodeposits, with consequences at farm- and larger spatial scales (Richard et al. 2007a; Woods et al. 2012; Lacoste \& Gaertner-Mazouni 2016). Increased biodeposition to the seafloor is recognized to change benthic community structure at both large and small spatial scales, depending on farm layout and environmental conditions (Hartstein \& Rowden 2004; McKindsey et al. 2011). The subsequent impacts of those changes on benthic ecosystem functioning (e.g. nutrient cycling, trophic cascading) have only rarely been addressed in the context of aquaculture (but see Heilskov et al. 2006; Lacoste et al. 2019). Studies have shown that diversity of biofouling communities in the water column may influence ecosystem functioning since it is, in part, responsible for variations in nutrient fluxes at the culture structure - water column interface in different ecosystems (Mazouni et al. 2001; Richard et 
al. 2006; Jansen et al. 2011; Lacoste et al. 2014).

As pointed out by Snelgrove et al. (2014), the effective application of biodiversity-ecosystem function $(\mathrm{BEF})$ research to societal needs in the Anthropocene represents the next great challenge for ecology. BEF studies may help understand how ecosystems work and respond to changes. In this sense, aquaculture seems an ideal opportunity to apply BEF research to elucidate impacts of anthropogenic disturbance on ecosystem diversity and functioning (and services). As such, organic loading in the form of bivalve biodeposition could serve as a model system to describe links between benthic community diversity and ecosystem functioning in terms of either nutrient or oxygen fluxes at the sediment-water interface or trophic links.

In this review, we highlight aquaculture-related modifications (focusing on off-bottom bivalve aquaculture) and suggest a holistic approach that includes studies done within a BEF framework to link biodiversity changes to ecosystem functioning. As a previous review emphasized the role of water column diversity (i.e. commercial species and biofouling communities) on ecosystem functioning (Lacoste \& Gaertner-Mazouni 2015), we here focus on the benthic compartment. We wish to demonstrate that further empirical studies are needed to adopt a holistic vision - i.e. by simultaneously considering environmental parameters, multi-level biodiversity descriptors (including functional diversity), and ecosystem functioning indicators.

\section{Impacts of bivalve aquaculture on the benthic ecosystem}

Bivalve aquaculture affects the environment in different ways, with a variety of near- and far-field cascading effects. Studies on the interactions between culture systems and natural environments are important for analysing and managing the environmental effects of aquaculture and vice versa. Although the following section provides an update of previous reviews (Prins et al. 1998; Cranford 
et al. 2003; Newell 2004; Forrest et al. 2009, Dumbauld et al. 2009; McKindsey et al. 2011) it does

111 not present an exhaustive review of the positive or negative impacts of aquaculture on the

112 environment; rather we highlight the complexity of ecosystem responses and the difficulty of finding

113 relevant indicators (see Valenti et al. 2018) given the variety and heterogeneity of studied systems.

114 Table 1 synthesizes the main ecosystem properties that are evaluated in aquaculture-environment 115 interactions studies.

\section{Benthic loading impacts sediment characteristics and nutrient exchanges}

118 Part of the material filtered by bivalves is excreted as feces or pseudo-feces, collectively known as

119 biodeposits, in the water column. Biodeposits have a greater sinking velocity than their constituent 120 particles thereby increasing sedimentation rates within suspended bivalve culture sites (Callier et al.

121 2006; Giles et al. 2006; Zúñiga et al. 2014). Biodeposit production and sedimentation rates vary 122 among species, bivalve sizes and diets, and vary greatly over short time scales (days). Waste 123 dispersal around shellfish farms has been modelled for few systems (Giles et al. 2009; Weise et al. 124 2009), and there is an acknowledged need to gather further information on biodeposit production 125 and composition under natural conditions, and the redistribution and integration of biodeposits once 126 they reach the seafloor. Improved predictions also requires a consideration of the communities that 127 live associated with cultured bivalves (including the species living on the structure, on and among 128 bivalve clumps) since they may significantly contribute to benthic organic loading (Lacoste \& 129 Gaertner-Mazouni 2015 and references therein). Notwithstanding the above, it is clear that 130 suspended bivalves may greatly increase sedimentation rates under farms relative to that in reference 131 areas. Zúñiga et al. (2014) found that sedimentation fluxes under mussel rafts in Spain (86-536 g $132 \mathrm{~m}-2 \mathrm{~d}-1$ ) was 6-7 folds the rate observed at a reference site, although the highly hydrodynamic 
133

134

135

environment attenuates the organic carbon arriving at the seafloor. Giles and Pilditch (2006) showed that sedimentation under a mussel farm in New Zealand (240-540 g m-2 d-1) was increased by $106 \mathrm{~g}$ m-2 d-1 compared to the reference site. In contrast, Comeau et al. (2014) did not observe differences in organic sedimentation rates under experimental mussel rafts compared to neighbouring reference sites in Canada.

Given high variability of biodeposition patterns, subsequent impacts of organic loading on sediment characteristics range from low (Danovaro et al. 2004; Mallet et al. 2006; Holmer et al. 2015), to slight (McKindsey et al. 2012; Dimitriou et al. 2015) to severe (Stenton-Dozey et al. 2001; Hargrave et al. 2008a; Cranford et al. 2009). The main changes described by several authors in association with biodeposit loading in shellfish areas are increased sediment organic material content (\%OM) or total free sulphides (TFS) or decreased redox potential (RedOx) (Hargrave et al. 2008a; Cranford et al. 2009; Comeau et al. 2014). However, several studies have shown that TFS and RedOx are often not sensitive enough to detect the effect of mussel aquaculture on benthic sediments (Callier et al. 2007; Comeau et al. 2014; Lacoste et al. 2019). The authors concluded that sedimented organic material may be rapidly processed by infauna communities or be resuspended, preventing negative effects of shellfish biodeposition on benthic sediments. The capacity of the benthic system to mineralize biodeposition in the short term is a key process that defines sediment \%OM increases. Accumulation of biodeposits on the seafloor and OM processing may further modify oxygen and nutrient exchanges at the sediment-water interface. Many studies have shown that benthic oxygen consumption is increased under aquaculture structures relative to that outside of farms (Giles \& Pilditch 2006; Nizzoli et al. 2006; Thouzeau et al. 2007) as are benthic ammonium and phosphate releases (Giles et al. 2006; Nizzoli et al. 2006; Richard et al. 2007b; Erler et al. 2017) due to the mineralization of accumulated OM. In deep areas or those with strong hydrodynamic conditions, 
156 biodeposit dispersion and degradation reduce the amount of organic material that arrives at the

157 seafloor, attenuating expected impacts on benthic biogeochemistry and nutrient fluxes (Gallardi

158 2014; Lacoste \& Gaertner-Mazouni 2016; Lacoste et al. 2018a).

159

160 One of the current challenges for environmental impact assessment of aquaculture is the

161 quantification of links between organic loading from biodeposition and biogeochemical and benthic

162 community conditions to inform predictive models. To our knowledge, only Weise et al. (2009) have

163 described a relationship between predicted biodeposition to the seafloor (using shellfish DEPOMOD

164 model) and benthic communities. This study observed decreased values for infaunal trophic index

165 scores (ITI, Word 1979) - an index of the tolerance of the benthic communities to organic enrichment

166 - with increasing predicted biodeposit fluxes. Given the complexity of interactions occurring in

167 sediments and the plethora of production systems, further empirical studies are needed to quantify

168 these relationships.

169

\section{Benthic community diversity}

171 Typically, the accumulation and decomposition of biodeposits from cultured bivalves affects benthic

172 communities according to the Pearson and Rosenberg (1978) model of organic enrichment, with a

173 progressive appearance of opportunistic species (e.g. Capitella spp.) directly under and in the

174 vicinity of aquaculture facilities. Many studies over the past 30 years have reported results on this

175 topic for different cultivated species and ecosystems (see reviews of Newell 2004; Forrest et al.

176 2009; McKindsey et al. 2011) but without showing consistent effects. Some authors have reported a

177 lower diversity of infaunal species (Chamberlain et al. 2001; Stenton-Dozey et al. 2001; Hartstein

178 \& Rowden 2004) and a dominance of opportunistic species beneath mussel farms (Mirto et al. 2000; 
179 Chamberlain et al. 2001; Hartstein \& Rowden 2004; Callier et al. 2007), whereas others have

180 detected minor (Brizzi et al. 1995; Mirto et al. 2000; Grant et al. 2012) or no negative effects on

181 macrofaunal community structure (Crawford et al. 2003; Danovaro et al. 2004; Miron et al. 2005;

182 Mallet et al. 2006). In some cases, shellfish aquaculture also promotes benthic macrofauna biomass

183 and diversity (Grant et al. 1995; Callier et al. 2007; D’Amours et al. 2008; Theodorou et al. 2015).

184 To date, most studies have focused on macrofauna (i.e. the fraction $>500 \mu \mathrm{m}$ or $>1 \mathrm{~mm}$, depending

185 on the study). To complete the description of community changes in the context of aquaculture, there

186 is also a need to identify benthic compartments other than macrofauna, such as meiofauna and

187 bacteria. Few studies have described responses of these communities to organic loading due to

188 bivalve biodeposition (Mirto et al. 2000; Danovaro et al. 2003; Mahmoudi et al. 2008; Pollet et al.

189 2015; Lacoste et al. 2019) although these compartments may respond quickly to disturbance

190 (Zeppilli et al. 2015 and references therein) and play a fundamental role in biogeochemical cycles

191 (Schratzberger \& Ingels 2017).

192 Analysis of community changes associated with aquaculture facilities includes univariate analysis

193 of diversity indices (e.g. richness, abundance, Shannon) as well as multivariate analyses to describe

194 community taxonomic composition (e.g. ordination techniques). Other alternative biotic indicators

195 may also be used (e.g. AZTI's Marine Biotic Index (AMBI, Borja et al. 2000) or ITI) but the results

196 are very context-dependent and appear to not be useful in all cases. Few studies have evaluated

197 benthic invertebrate functional diversity in the context of fish (Dimitriadis \& Koutsoubas 2011) or

198 shellfish (Lacoste et al. 2019) aquaculture. However, it is increasingly recognized that integrating

199 functional information (on the basis of species trait values) deepens understanding of community

200 functioning (Diaz \& Cabido 2001). 
202 To date, the range of aquaculture impacts reported in the literature is largely based on ecological 203 indices for macro-infauna (Miron et al. 2005; Borja et al. 2009). The species diversity approach to

204 describing aquaculture impacts is thus incomplete as it ignores some compartments and the 205 functional consequences of species assemblage modifications on ecosystem processes. We suggest 206 that a more holistic understanding of the effect of bivalve culture on ecosystem processes would be 207 gained by using a multi-indicator approach, including functional ones, based on several taxonomic 208 levels (from bacteria to macrofauna).

Table 1. Overview of the main impacts of suspended bivalve aquaculture on the benthic ecosystem described in aquaculture-environment interactions studies (not exhaustive). Studies are divided into those that concentrated on 1) only sediment biogeochemistry, 2) benthic communities (macrofauna and meiofauna and/or bacteria), 3) sediment-water interface (SWI) fluxes and 4) both benthic communities and SWI fluxes.

\begin{tabular}{|c|c|c|c|c|c|}
\hline Benthic diversity & $\begin{array}{l}\text { Ecosystem } \\
\text { functioning }\end{array}$ & Sediment biogeochemistry & Culture type & Sites & References \\
\hline \multirow[t]{4}{*}{-} & - & $\begin{array}{l}\text { Sedimentation, sediment OM } \\
\text { content, sulfides, redox } \\
\text { potential }\end{array}$ & $\begin{array}{l}\text { longlines, } \\
\text { mussels }\end{array}$ & Canada & $\begin{array}{l}\text { Hatcher et al. } 1994 \\
\text { Callier et al. } 2006 \\
\text { Hargrave } \text { et al. } 2008 \text { a } \\
\text { Cranford et al. } 2009 \\
\text { Weise et al. } 2009\end{array}$ \\
\hline & & & $\begin{array}{l}\text { floating bags \& } \\
\text { table, oysters }\end{array}$ & & Mallet et al. 2006 \\
\hline & & & raft, oysters & & Comeau et al. 2014 \\
\hline & & & $\begin{array}{l}\text { raft farm, } \\
\text { mussels }\end{array}$ & Spain & Zúñiga et al. 2014 \\
\hline \multirow[t]{6}{*}{$\begin{array}{l}\text { Macro-infaunal } \\
\text { communities }\end{array}$} & - & $\begin{array}{l}\text { Grain size, sediment OM } \\
\text { content }\end{array}$ & $\begin{array}{l}\text { longlines, } \\
\text { mussels }\end{array}$ & Ireland & $\begin{array}{l}\text { Chamberlain et al. } \\
2001\end{array}$ \\
\hline & & & $\begin{array}{l}\text { oysters \& } \\
\text { mussels }\end{array}$ & Australia & Crawford et al. 2003 \\
\hline & & & $\begin{array}{l}\text { longlines, } \\
\text { mussels }\end{array}$ & $\begin{array}{l}\text { New } \\
\text { Zealand }\end{array}$ & $\begin{array}{l}\text { Hartstein and Rowden } \\
2004\end{array}$ \\
\hline & & & $\begin{array}{l}\text { longlines, } \\
\text { mussels }\end{array}$ & Canada & $\begin{array}{l}\text { Callier et al. } 2008 \\
\text { McKindsey et al. } \\
2009,2012\end{array}$ \\
\hline & & & $\begin{array}{l}\text { longlines, } \\
\text { mussels }\end{array}$ & Italy & Fabi et al. 2009 \\
\hline & & & mussels & $\begin{array}{l}\text { New } \\
\text { Zealand }\end{array}$ & $\begin{array}{l}\text { Wong and O'Shea } \\
2011\end{array}$ \\
\hline
\end{tabular}




\begin{tabular}{|c|c|c|c|c|c|}
\hline & & & $\begin{array}{l}\text { bouchot } \\
\text { mussels }\end{array}$ & France & Grant et al. 2012 \\
\hline & & & raft, mussels & Scotland & $\begin{array}{l}\text { Wilding and Nickell } \\
2013\end{array}$ \\
\hline & & & $\begin{array}{l}\text { longlines, } \\
\text { mussels }\end{array}$ & Greece & Dimitriou et al. 2015 \\
\hline & & & $\begin{array}{l}\text { offshore } \\
\text { longlines, } \\
\text { mussels }\end{array}$ & Canada & Lacoste et al. $2018 \mathrm{a}$ \\
\hline $\begin{array}{l}\text { Meiofauna and/or } \\
\text { Bacteria }\end{array}$ & - & $\begin{array}{l}\text { Sedimentation, grain size, } \\
\text { redox potential }\end{array}$ & $\begin{array}{l}\text { longlines, } \\
\text { mussels }\end{array}$ & Italy & $\begin{array}{l}\text { Mirto et al. } 2000 \\
\text { Danovaro et al. } 2004\end{array}$ \\
\hline & & & $\begin{array}{l}\text { control } \\
\text { experiment, } \\
\text { mussels }\end{array}$ & Canada & Pollet et al. 2015 \\
\hline- & SWI fluxes & $\begin{array}{l}\text { Grain size, sediment OM } \\
\text { content }\end{array}$ & table, oysters & France & $\begin{array}{l}\text { Mazouni et al. } 1996 \\
\text { Mazouni } 2004\end{array}$ \\
\hline & & & mussels & $\begin{array}{l}\text { New } \\
\text { Zealand }\end{array}$ & $\begin{array}{l}\text { Giles and Pilditch } \\
2006 \\
\text { Giles et al. } 2006\end{array}$ \\
\hline & & & ropes, mussels & Italy & $\begin{array}{l}\text { Nizzoli et al. 2005, } \\
2006,2011\end{array}$ \\
\hline & & & $\begin{array}{l}\text { Longlines, } \\
\text { mussels }\end{array}$ & Canada & Richard et al. 2007a,b \\
\hline & & & Rafts, mussels & Spain & $\begin{array}{l}\text { Alonso-Perez et al. } \\
2010\end{array}$ \\
\hline & & & $\begin{array}{l}\text { longlines, } \\
\text { pearl-oysters }\end{array}$ & $\begin{array}{l}\text { French } \\
\text { Polynesia }\end{array}$ & $\begin{array}{l}\text { Gaertner-Mazouni et } \\
\text { al. } 2012\end{array}$ \\
\hline & & & oysters & Australia & Erler et al. 2017 \\
\hline $\begin{array}{l}\text { Macro-infaunal } \\
\text { communities }\end{array}$ & SWI fluxes & $\begin{array}{l}\text { Grain size, sediment OM } \\
\text { content, sulphides, redox } \\
\text { potential }\end{array}$ & raft, mussels & $\begin{array}{l}\text { South } \\
\text { Africa }\end{array}$ & $\begin{array}{l}\text { Stenton-Dozey et al. } \\
2001\end{array}$ \\
\hline & & & $\begin{array}{l}\text { longlines, } \\
\text { mussels }\end{array}$ & $\begin{array}{l}\text { New } \\
\text { zealand }\end{array}$ & $\begin{array}{l}\text { Christensen et al. } \\
2003\end{array}$ \\
\hline & & & $\begin{array}{l}\text { mesocosms, } \\
\text { mussels }\end{array}$ & Canada & Callier et al. 2009 \\
\hline & & & $\begin{array}{l}\text { mesocosms, } \\
\text { mussels }\end{array}$ & & Robert et al. 2013 \\
\hline & & & $\begin{array}{l}\text { mesocosms, } \\
\text { mussels }\end{array}$ & & Lacoste et al. 2019 \\
\hline
\end{tabular}




\section{Ecosystem-wide effects}

217 While benthic conditions are the most thoroughly studied impacts related to marine aquaculture, 218 other risk factors remain less clear. For example, impacts (e.g. vulnerability to disease, genetic, 219 trophic transfers) on populations of mobile macro-organisms, such as crustaceans, have been rarely 220 quantified (see Callier et al. 2017 for a review). However, the addition of aquaculture-related 221 physical structure in the environment creates refuges from predation and adverse environmental conditions (Gutierrez et al. 2003) and fall-off of cultivated and associated organisms may serve as food sources for wild populations (Miron et al. 2002; D’Amours et al. 2008) and attract mobile organisms to farms. Several studies have shown that many fishes may be attracted to farm sites as they feed on bivalve-associated organisms (Carbines 1993; Brooks 2000; Gerlotto et al. 2001; Cartier \& Carpenter 2013) and, in turn, be a food source for other predators (Brehmer et al. 2003). In general, a higher density and diversity of wild fish is observed at farms relative to reference areas, suggesting that aquaculture facilities act as fish aggregating devices (Barret et al. 2018). The extent to which these animals are attracted to the structure itself (e.g. as a refuge from predators) or to the 230 prey associated with the structure is unclear (Würsig \& Gailey 2002) and is likely species-specific.

231 For example, Drouin et al. (2015) showed that lobster Homarus americanus is more attracted by the shelter created by mussel farming anchors whereas winter flounder Pseudopleuronectes americanus 233 seems to benefit from a trophic effect induced by the farm.

234 Conversely, aquaculture may also repulse some organisms by displacing their habitat or due to 235 disturbances created by husbandry activities. For example, Becker et al. (2011) suggested that three 236 decades of shellfish aquaculture have displaced breeding and pupping harbour seals. Kelly et al. (1996) also showed that some birds avoid areas used for shellfish aquaculture, resulting in a net 238 decrease of overall shorebird use of open tidal flats that have been used for aquaculture. 
239 Recently, a few studies have explored the direct trophic interactions between bivalve aquaculture

240 and wild populations. Using stable isotope analysis, Huang et al. (2018) showed that scallop faeces

241 may serve as new food source for benthic organisms, including meiofauna, further improving the

242 quality of lower level consumers as a food item in the benthic food web. Such results are important

243 and should be further explored since cascading effects to higher trophic levels could have a crucial

244 importance for ecosystem functioning, including on commercial species. A recent study (Sardenne

245 et al. 2019) showed that fallen farmed mussels contributed almost half of the diet of large lobsters

246 whereas small lobsters fed mostly on farm-associated crabs. In Norway, work has shown that wastes

247 from salmon farms may be transferred and picked up by organisms over significant distances (500

$248 \mathrm{~m}$ to $>1 \mathrm{~km}$ ), although the impacts of this on animals that assimilate such wastes may have

249 ecosystem-level consequences (White et al. 2017; Woodcock et al. 2018). Thus, impacts may

250 include both ecological effects and effects on the fisheries due to altered productivity, distribution,

251 or catchability of target species.

252 This field of research remains largely unexplored and should be addressed to place aquaculture253 related effects in context with other activities (e.g. fisheries) in areas where they may overlap.

Predicting the impacts of bivalve aquaculture on the benthic system using the biodiversity

256 ecosystem functioning (BEF) framework

257 The main influences of bivalve culture on the sea floor were highlighted in the previous section.

258 Most studies on aquaculture-environment interactions to date have assessed a single or limited 259 number of potential effects (e.g. modification of macrofaunal diversity and sulfides) whereby links

260 between disturbances and functioning are only addressed superficially (Table 1). Although some 261 studies have measured benthic diversity and benthic fluxes simultaneously, few have explored the 
262 functional role of species in nutrient dynamics. We here propose a more holistic approach for 263 studying aquaculture-environment interactions based on the BEF framework. The main concepts of 264 this approach are represented in Fig. 2.

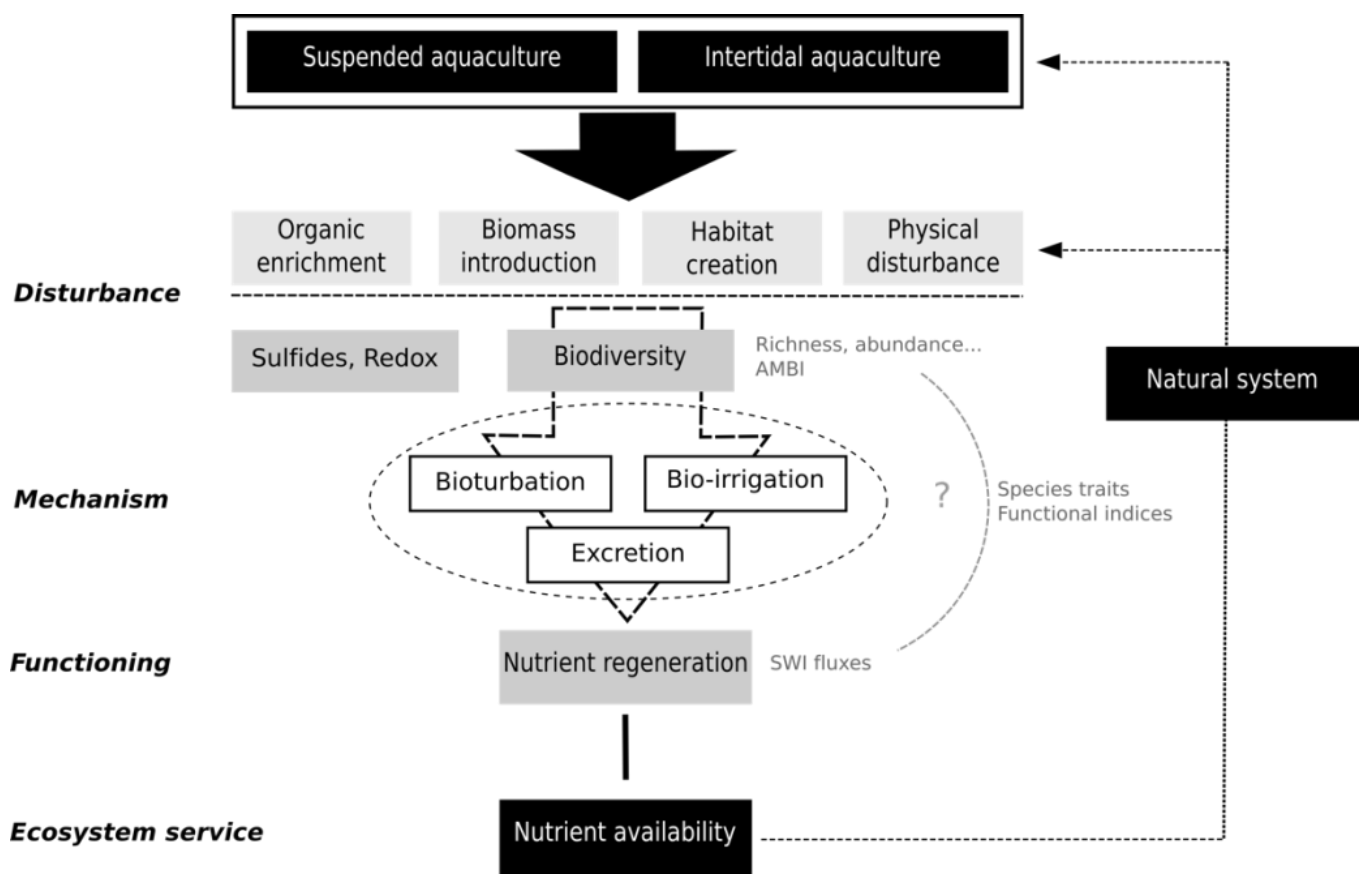

267 Figure 2. BEF approach to the bivalve aquaculture-environment interactions for benthic systems 268 with a focus on nutrient availability as an example of ecosystem service. The main idea is to explore 269 the mechanisms at the origin of ecosystem functioning to better predict the impacts of disturbances 270 due to aquaculture.

\section{Status of knowledge and limitations in marine systems}

273 Following initial studies on terrestrial ecosystem functioning (Gamfeldt et al. 2014), the number of 274 manipulative experiments to assess BEF relationships in marine systems has rapidly increased

275 (Cardinale 2011; Solan et al. 2012). Several studies focusing specifically on sediment processes have 276 shed light on the major role of benthic organisms on organic transfers in coastal ecosystems (Cloern 277 1982; Chauvaud et al. 2000; Grall \& Chauvaud 2002). Sediment communities drive many critical 
ecosystem functions, in particular nitrogen recycling, which is usually the driver of eutrophication processes. In shallow environments, inorganic nitrogen regeneration in sediments can provide between $20 \%$ and $100 \%$ of the annual requirement for primary production (Welsh 2003) and thus understanding the mechanisms that drive this cycling is a key to understanding coastal productivity. Laboratory and field studies have shown the significant effect of macrofauna on ecosystem processes through sediment particle reworking (bioturbation), solute transfers in sediments (bio-irrigation), and impacts on microbial processes, each of which alter the flow of energy and matter (Solan et al. 2004; O'Connor \& Crowe 2005; Ieno et al. 2006; Waldbusser \& Marinelli 2006). A large body of scientific work has clearly shown how burrowers import $\mathrm{O}_{2}$ into their burrows and enhance microbial aerobic activity via intermittent ventilation (Kristensen 1988, 2000; Glud 2008). Nevertheless, many of these studies are laboratory experiments using a single macrofaunal species (but see Kristensen $e t$ al. 2014; Belley \& Snelgrove 2016; Politi et al. 2019). Such simple communities do not consider ecological interactions present among organisms such as predation, competition or facilitation which may greatly influence processes, including nutrient regeneration. Thus, although the roles of macrofauna (via bioturbation and bio-irrigation) may be well-identified, more integrated approaches require further knowledge, in particular concerning the roles of other biological compartments, such as meiofauna and bacteria. In particular, there is a recent and growing interest to study the role of meiofauna, since it has been shown that these organisms may modulate the biological interactions within sediments (Bonaglia et al. 2014; Lacoste et al. 2018b) and play a significant role in benthic ecosystem processes and services (Schratzberger \& Ingels 2017). Until now, the paucity of information on this group likely reflects the labour-intensive nature of obtaining such data, which is particularly demanding both in terms of field work and species identification. New tools (e.g. 
metabarcoding) could provide the opportunity to progress in this sense as has been shown by recent studies (Boufahja et al. 2015; Carugati et al. 2015).

The effect of a species' behaviour on biogeochemical processes is now widely based on functional 303 groups, which, for benthic species, may be defined according to bioturbation mode, depth of 304 burrowing, or feeding guild (Solan et al. 2004; Piot et al. 2014; Wrede et al. 2017). Given the 305 importance of species identity, it is now accepted that species diversity alone does not guarantee the stability of ecosystems or their resistance to disturbances (Mouillot et al. 2013; Gagic et al. 2015; 307 Jacquet et al. 2016) since the loss of a given species may also lead to the loss of a specific function 308 and thus alter ecosystem biological and chemical processes. As an example, Dubois et al. (2007) observed changes in trophic pathways between two benthic communities without apparent changes 310 of the overall taxonomic diversity. Those changes were attributed to the replacement of filter-feeders 311 usually associated with the tube worms Lanice conchilega, in oyster farming areas. Conversely, 312 apparent changes of taxonomic diversity may be buffered by functional redundancies in communities 313 (Walker 1992; Snelgrove 1998) such that functional impacts on benthic assemblages are not always 314 matched by their structural counterparts (Bolam 2012). Thus, the removal of a highly functionally315 redundant species from a community may not result in a substantial reduction of community 316 functions, although this could be context dependent especially in case of ecosystem disturbance 317 (Hiddink et al. 2009). This potential decoupling between taxonomic diversity and ecosystem 318 functioning indicates that a functional based approach of diversity should be preferred to investigate 319 the effect of human disturbance at the ecosystem-functioning level (Mouillot et al. 2006, 2013).

320 While the functional approach is becoming a major concept in ecology and ecosystem management, 321 there are several gaps that cause uncertainty in ecological interpretations and limit comparisons 322 across studies. A main challenge is the limited availability of biological and ecological traits for 
323 marine species, although some databases of traits are now available (Faulwetter et al. 2014).

324 Although there are multiple methods to measure functional diversity (Villéger et al. 2008; Laliberté

325 \& Legendre 2010; Mouchet et al. 2010), to date, there is no standard accepted methodology to select

326 the most appropriate traits to compute the different indices (Marchini et al. 2008). Thus, until a

327 unified framework is adopted, the choice of the number of functional traits is partly based on

328 subjective rationale (Hortal et al. 2015; de Bello et al. 2017).

\section{BEF approach to study aquaculture-environment interactions}

331 Wild sessile populations, particularly infauna, are commonly used as indicators of farm 332 environmental performance as these organisms integrate effects on benthic sediments. Changes in 333 community structure brought about by bivalve farming activities may also be expected to affect

334 sediment oxygen and nitrogen dynamics. To date, field experiments have tested the responses of 335 macro-faunal communities whereas others have measured effects on ecosystem functions including 336 nutrient fluxes; few studies have examined the two and assessed the feedback of macrofauna on 337 fluxes in response to organic enrichment in bivalve aquaculture (Table 1). Lacoste et al. (2019) 338 showed that benthic responses (measured as SWI nutrient fluxes) may not be linearly related to 339 organic enrichment (mussel biodeposits), likely due to varying responses of infaunal organisms with 340 different functional roles. Some species that benefit from intermediate organic enrichment may have 341 a positive effect on nutrient release to the water column whereas, at higher levels of enrichment, 342 large bio-irrigating species (Cistenides gouldii) may be lost with a net negative effect on 343 mineralization. Similar results have been observed around fish farms where mineralization rates were 344 highly correlated with the presence of the large and active irrigating climax species Hediste 345 diversicolor and Limecola balthica (Heilskov et al. 2006). It is not straightforward to infer immediate 
346 effects of organic enrichment on nutrient regeneration and cascading effects on whole ecosystem

347 nutrient dynamics because of the idiosyncratic role of species and the importance of sediment

348 characteristics. Nonetheless, the exercise seems important given the myriad uses of coastal areas and

349 the potential impacts that aquaculture may have on the functioning these ecosystems. Empirical

350 studies are needed to advance theoretical and methodological knowledge to further understand these

351 relationships. Thus, dose-response studies are an interesting approach to evaluate thresholds at which

352 changes in community diversity may alter ecosystem functioning. The contrasting benthic conditions

353 created by aquaculture along gradients may also represent an excellent opportunity to empirically

354 evaluate the effects of diversity modifications on benthic fluxes under field conditions. Although

355 some studies have addressed this point with experimental (Callier et al. 2009; Robert et al. 2013;

356 Lacoste et al. 2019) and natural (Dimitriadis \& Koutsoubas 2011) gradients of organic enrichment

357 for bivalve and fish farm systems, further investigations are required that simultaneously consider

358 changes of benthic functional diversity and consequences for ecosystem functioning.

359 Knowledge of species' functional roles may further serve to improve sediment quality of organically

360 enriched sediments in the context of mitigating negative aquaculture effects (Slater \& Carton 2009;

361 2010; Bergström et al. 2015, 2018). In a series of field and laboratory experiment, Bergström et al.

362 (2015) demonstrated the contribution of the gallery-building polychaete Hediste diversicolor to the

363 degradation of organic material beneath mussel farms. They estimated that polychaetes activity

364 stimulated the degradation of up to $80 \%$ of organic material reaching the bottom every day. The role

365 of the polychaete may be direct through the consumption of faecal pellets at the sediment surface or

366 indirect through the stimulation of bacterial processes in deeper sediment layers. Further worm

367 species have been identified that could help mitigate aquaculture wastes while producing additional

368 farmed marine biomass in integrated multitrophic aquaculture (IMTA) (Pombo et al. 2018). 
370 The identification of potential candidates to mitigate wastes from aquaculture requires a deep

371 knowledge of species ecology and behaviour within sediments and on the relationships with ecosystem processes that a BEF approach could inform. Aquaculture research offers a tremendous opportunity to contrast environments with the same species being cultivated around the world and thus improve our understanding of aquaculture - diversity - ecosystem functioning relationships. In line with Strong et al. (2015), who proposed a practical monitoring application of BEF relationships

for the marine realm, we believe that there would be a benefit to provide surrogate indicators of aquaculture impacts on ecosystem functionality based on a BEF approach.

\section{BEF approach to maintain ecosystem functioning and services}

380 The idea behind using BEF approach in AEI studies relies on the development of predictive tools to

381 assess the impacts of aquaculture on whole ecosystem functioning in areas where bivalve farming is extensively practiced. This is in line with the ecosystem approach to aquaculture (EAA) (Soto et al. 2008; Aguilar-Manjarrez et al. 2010) which states that development and management of this industry

384 should take account of the full range of ecosystem functions and services and should not threaten their sustained delivery to society. Today, standard monitoring of shellfish culture sites is not required in most jurisdictions (e.g. in Europe and Canada), and thus the level of impact and science recommendations are currently only informative. Moreover, "classic" indicators used to evaluate aquaculture impacts (e.g. sulphide levels, species richness) provide information on how benthic sediments are affected, but do not set limits as to what is "acceptable" or "unacceptable" regarding a reference ecosystem state. Moving towards predicting aquaculture impacts in relation to whole

391 ecosystem functioning and service delivery would thus seem of interest for both society and decision 
makers. Hargrave et al. (2008b) proposed a "nomogram" to classify benthic enrichment zones based on different biogeochemical variables. Zones were defined to range from oxic to anoxic with different indicators values and corresponding effects on macrobenthic infaunal biodiversity. Such a unified model would be useful to identify benthic habitat quality as defined for example in the EU Water Framework Directive (EC, 2000). However, whether these empirical relationships are applicable in many ecosystems requires further study since sediment composition (e.g. grain size, silt or sand), for example, greatly influences biogeochemical processes (Martinez-Garcia et al. 2015). Recently, Brigolin et al. (2017) proposed a biogeochemical model to quantify benthic recycling of organic matter under contrasted forcing linked to mussel farms (i.e. POC deposition fluxes). To our knowledge, this is the only study to have estimated the direct effect of mussel 402 biodeposition on biogeochemical processes in sediments. The model suggested that greater 403 mineralization of organic matter with increased oxygen consumption would occur below mussel 404 farms relative to reference sites. Coupled with dose-response experiments, such a modeling approach 405 could contribute to developing a deeper understanding of the global impact of aquaculture on ecosystem functioning and to, for example, attempt to quantify eutrophication in coastal waters.

407 Whereas eutrophication is one of the greatest global threats to the marine environment, the place of 408 aquaculture in the eutrophication process remains unpredictable and debated (Bergström 2014). On 409 the one hand, some studies conclude that filter feeding bivalves can contribute to the net removal of 410 nitrogen from coastal environments through the incorporation into animal tissue and enhanced 411 denitrification in underlying sediments (Edebo et al. 2000; Carlsson et al. 2012; Smyth et al. 2013). 412 These effects have led several authors to suggest that shellfish aquaculture could mitigate 413 eutrophication in coastal waters (Cerco \& Noel 2007; Bricker et al. 2014; Rose et al. 2014). 414 However, enhanced denitrification under aquaculture sites does not always occur (Kellog et al. 2014) 
415 and other researchers have expressed concern that this approach could have negligible positive 416 effects or even negative effects (Newell 2004; Pomeroy et al. 2006; Fulford et al. 2010; Carmichael

417 et al. 2012). There is also strong evidence to suggest that bivalve cultivation may have a positive 418 effect on the nutrient pools in the water column due to the constant excretion of inorganic nutrients 419 by the cultivated organisms and nutrient export (instead of denitrification) from the underlying 420 sediments (Christensen et al. 2003; Nizzoli et al. 2006, 2011; Murphy et al. 2016; Erler et al. 2017).

421 Overall, there remains ambiguity surrounding the magnitude and direction of $\mathrm{N}$ losses in bivalve 422 aquaculture systems due to uncertainty about the different nitrate reduction pathways including denitrification, anammox and dissimilatory nitrate reduction to ammonium.

\section{Future research directions}

426 In this review, we wanted to highlight the possibility that a BEF approach may increase our 427 understanding of aquaculture-environment interactions, with an ultimate goal to provide advice for 428 a sustainable development of the industry in accordance with other multiple uses of marine areas, 429 including the conservation of wild species and habitat. The recently developed functional approach 430 represents a great opportunity to deepen our knowledge of the links between modifications of benthic 431 diversity under bivalve farms and the implications for ecosystem processes, as measured through 432 nutrient fluxes or food webs, and more largely on ecosystem service delivery. Such knowledge will 433 serve for future management and policy that consider the adequacy of marine use and service 434 delivery with ecosystem integrity preservation.

435 Through our literature review, we identified several gaps that represent many research opportunities 436 to improve our knowledge of fundamental drivers of sediment processes impacted by a local source 
437 of disturbance, such as organic enrichment from biodeposition, in a framework where we consider

438 the impacts of aquaculture on ecosystem functioning and services:

439 - Investigating the role of further taxonomic groups (i.e. bacteria and meiofauna) in

440 aquaculture-environment interactions studies whose influence on sediment processes may be

$441 \quad$ of great importance;

442 - Simultaneously considering sediment characteristics, biodiversity and ecosystem function

443 indicators to model the influence of biodeposition on the whole ecosystem and improve our

$444 \quad$ understanding of BEF relationships;

445 - Developing tools to predict the impact of aquaculture on nutrient budgets as a surrogate of

$446 \quad$ eutrophication level;

447 - Developing models linking bivalve biodeposition to benthic biogeochemical processes to

$448 \quad$ prevent excessive organic loading leading to eutrophication;

449 - Investigating the effect of aquaculture on the trophic food web as a surrogate of ecosystem

$450 \quad$ functioning;

451 - Resolve the influence of aquaculture on the environment across a wide spectrum of 452 aquaculture practices (e.g. intertidal, coastal, offshore), habitats and environmental $453 \quad$ conditions (e.g. eutrophic, oligotrophic);

454 - Identifying potential benthic invertebrates that could act as mitigation tools in sediment 455 impacted by bivalve farms using the BEF framework. 


\section{Bibliography}

459

460

461

462

463

464

465

466

467

468

469

470

471

472

473

474

475

476

477

478

479

480

481

482

483

484

485

486

487

488

489

490

491

492

493

494

495

496

497

Aguilar-Manjarrez J, Kapetsky JM, Soto D (2010) The potential of spatial planning tools to support the ecosystem approach to aquaculture. Expert Workshop. 19-21 November 2008, Rome, Italy. FAO Fisheries and Aquaculture Proceedings No. 17. FAO, Rome. Available from URL: http://www.fao.org/docrep/012/i1359e/i1359e.pdf

Alonso-Pérez F, Ysebaert T, Castro CG (2010) Effects of suspended mussel culture on benthicpelagic coupling in a coastal upwelling system (Ría de Vigo, NW Iberian Peninsula). Journal of Experimental Marine Biology and Ecology 382: 96-107.

Andersen KH, Pedersen M (2009) Damped trophic cascades driven by fishing in model marine ecosystems. Proceedings of the Royal Society B: Biological Sciences 277(1682): 795-802.

Balvanera P, Siddique I, Dee L, Paquette A, Isbell F, Gonzalez A et al. (2014) Linking biodiversity and ecosystem services: Current uncertainties and the necessary next steps. Bioscience 64: 4957.

Barrett LT, Swearer SE, Dempster T (2018) Impacts of marine and freshwater aquaculture on wildlife: a global meta-analysis. Reviews in Aquaculture 11(4): 1022-1044

Becker BH, Press DT, Allen SG (2011) Evidence for long-term spatial displacement of breeding and pupping harbour seals by shellfish aquaculture over three decades. Aquatic Conservation in Marine and Freshwater Ecosystems 21: 247-260.

Belley R, Snelgrove PVR (2016) Relative contributions of biodiversity and environment to benthic ecosystem functioning. Frontiers in Marine Science 3: 242.

Bergström P (2014) Blue Oceans with Blue Mussels - Management and planning of mussel farming in coastal ecosystems. $\mathrm{PhD}$ Thesis, University of Gothenburg.

Bergström P, Carlsson MS, Lindegarth M, Petersen JK, Lindegarth S, Holmer M (2015) Testing the potential for improving quality of sediments impacted by mussel farms using bioturbating polychaete worms. Aquaculture Research 48: 161-176.

Bergström P, Hällmark N, Larsson K, Lindegarth M (2018) Biodeposits from Mytilus edulis: a potentially high-quality food source for the polychaete, Hediste diversicolor. Aquaculture International 27: 89-104.

Bolam SG (2012) Impacts of dredged material disposal on macrobenthic invertebrate communities: A comparison of structural and functional (secondary production) changes at disposal sites around England and Wales. Marine Pollution Bulletin 64: 2199-2210

Bonaglia S, Nascimento FJA, Bartoli M, Klawonn I, Brüchert V (2014) Meiofauna increases bacterial denitrification in marine sediments. Nature Communications 5: 5133

Borja A, Franco J, Perez V (2000) A Marine Biotic Index to establish the ecological quality of softbottom benthos within european estuarine and coastal environments. Marine Pollution Bulletin 40: $1100-1114$.

Borja Á, Rodríguez JG, Black K, Bodoy A, Emblow C, Fernandes TF et al. (2009) Assessing the suitability of a range of benthic indices in the evaluation of environmental impact of fin and shellfish aquaculture located in sites across Europe. Aquaculture 293: 231-240.

Boufahja F, Semprucci F, Beyrem H, Bhadury P (2015) Marine nematode taxonomy in Africa : 
Promising prospects against scarcity of information. Journal of Nematology 47: 198-206.

Brehmer P, Gerlotto F, Guillard J, Sanguinède F, Guénnegan Y, Buestel D (2003) New applications of hydroacoustic methods for monitoring shallow water aquatic ecosystems: The case of mussel culture grounds. Aquatic Living Resources 16: 333-338.

Bricker SB, Rice KC, Bricker OP (2014) From headwaters to coast: Influence of human activities on water quality of the Potomac River estuary. Aquatic Geochemistry 20: 291-323.

Bricker SB, Getchis TL, Chadwick CB, Rose CM, Rose JM (2016) Integration of ecosystem-based models into an existing interactive web-based tool for improved aquaculture decision-making. Aquaculture 453: 135-146.

Brigolin D, Rabouille C, Bombled B, Colla S, Vizzini S, Pastres R et al. (2017) Modelling biogeochemical processes in sediments from the north western Adriatic Sea: response to enhanced particulate organic carbon fluxes. Biogeosciences 15: 1347.

Brizzi G, Aleffi F, Goriup F, Landri P, Orel G (1995) Modificazioni nel benthos sul fondo delle mitilicolture nel Golfo di Trieste (Adriatico Settentrionale). Annali di Studi Istriani e Mediterranei 7: 17-26

Brooks KM (2000) Literature review and model evaluation describing the environmental effects and carrying capacity associated with the intensive culture of mussels (Mytilus edulis galloprovincialis). Unpublished technical report, Olympia, Washington 1-125.

Callier MD, Byron CJ, Bengtson DA, Cranford PJ, Cross SF, Focken U et al. (2017) Attraction and repulsion of mobile wild organisms to finfish and shellfish aquaculture: a review. Reviews in Aquaculture 10(4): 924-949.

Callier MD, McKindsey CW, Desrosiers G (2007) Multi-scale spatial variations in benthic sediment geochemistry and macrofaunal communities under a suspended mussel culture. Marine Ecology Progress Series 348: 103-115.

Callier MD, McKindsey C, Desrosiers G (2008) Evaluation of indicators used to detect mussel farm influence on the benthos: Two case studies in the Magdalen Islands, Eastern Canada. Aquaculture 278: 77-88

Callier MD, Richard M, McKindsey CW, Archambault P, Desrosiers G (2009) Responses of benthic macrofauna and biogeochemical fluxes to various levels of mussel biodeposition: An in situ "benthocosm" experiment. Marine Pollution Bulletin 58: 1544-1553

Callier MD, Weise AM, McKindsey CW, Desrosiers G (2006) Sedimentation rates in a suspended mussel farm (Great-Entry Lagoon, Canada): Biodeposit production and dispersion. Marine Ecology Progress Series 322: 129-141.

Carbines G (1993) The ecology and early life history of Notolabrus celidotus (Pisces: Labridae) around mussel farms in the Marlborough Sounds. MSc thesis, Department of Zoology. University of Canterbury.

Cardinale BJ (2011) Biodiversity improves water quality through niche partitioning. Nature 472: 86-91.

Cardinale BJ, Duffy JE, Gonzalez A, Hooper DU, Perrings C, Venail P et al. (2012) Biodiversity loss and its impact on humanity. Nature 489: 326-326.

Carlsson M, Engström P, Lindahl O, Ljungqvist L, Petersen J, Svanberg L et al. (2012) Effects of 
mussel farms on the benthic nitrogen cycle on the Swedish west coast. Aquaculture Environment Interactions 2: 177-191.

Carmichael RH, Walton W, Clark H (2012) Bivalve-enhanced nitrogen removal from coastal estuaries. Canadian Journal of Fisheries and Aquatic Sciences 69: 1131-1149.

Cartier LE, Carpenter KE (2013) The influence of pearl oyster farming on reef fish abundance and diversity in Ahe, French Polynesia. Marine Pollution Bulletin 78: 43-50.

Carugati L, Corinaldesi C, Dell'Anno A, Danovaro R (2015) Metagenetic tools for the census of marine meiofaunal biodiversity: An overview. Marine Genomics 24: 11-20.

Cerco CF, Noel MR (2007) Can oyster restoration reverse cultural eutrophication in Chesapeake Bay? Estuaries and Coasts 30: 331-343.

Cernansky R (2017) The biodiversity revolution. Nature 546: 22-24.

Chamberlain J, Fernandes TFT, Read P, Nickell TDT, Davies IMI (2001) Impacts of biodeposits from suspended mussel (Mytilus edulis L.) culture on the surrounding surficial sediments. ICES Journal of Marine Sciences 58: 411-416.

Chauvaud L, Jean F, Ragueneau O, Thouzeau G (2000) Long-term variation of the Bay of Brest ecosystem: Benthic-pelagic coupling revisited. Marine Ecology Progress Series 200: 35-48.

Christensen PB, Glud RN, Dalsgaard T, Gillespie P, Bondo P (2003) Impacts of longline mussel farming on oxygen and nitrogen dynamics and biological communities of coastal sediments. Aquaculture 218: 567-588.

Cloern J (1982) Does the benthos control phytoplankton biomass in South San Francisco Bay? Marine Ecology Progress Series 9: 191-202.

Comeau LA, Mallet AL, Carver CE, Guyondet T (2014) Impact of high-density suspended oyster culture on benthic sediment characteristics. Aquaculture Engineering 58: 95-102.

Cranford PJ, Dowd M, Grant J (2003) Ecosystem level effects of marine bivalve aquaculture. Canadian Technical Reports in Fisheries and Aquatic Sciences 2450: 51-96.

Cranford P, Hargrave B, Doucette L (2009) Benthic organic enrichment from suspended mussel (Mytilus edulis) culture in Prince Edward Island, Canada. Aquaculture 292: 189-196.

Crawford CM, Macleod CKA, Mitchell IM (2003) Effects of shellfish farming on the benthic environment. Aquaculture 224: 117-140.

D'Amours O, Archambault P, McKindsey CW, Johnson LE (2008) Local enhancement of epibenthic macrofauna by aquaculture activities. Marine Ecology Progress Series 371: 73-84.

Danovaro R, Corinaldesi C, La Rosa T, Luna GM, Mazzola A, Mirto S et al. (2003) Aquaculture impact on benthic microbes and organic matter cycling in coastal Mediterranean sediments: A synthesis. Chemical Ecology 19: 59-65.

Danovaro R, Gambi C, Luna GM, Mirto S, (2004) Sustainable impact of mussel farming in the Adriatic Sea (Mediterranean Sea): evidence from biochemical, microbial and meiofaunal indicators. Marine Pollution Bulletin 49: 325-333.

de Bello F, Šmilauer P, Diniz-Filho JAF, Carmona CP, Lososová Z, Herben T et al. (2017) Decoupling phylogenetic and functional diversity to reveal hidden signals in community assembly. Methods in Ecology and Evolution 8: 1200-1211. 
Dempster T, Holmer M (2009) Introducing the new multidisciplinary journal aquaculture environment interactions. Aquaculture Environment Interactions 1:i-ii.

Díaz S, Cabido M (2001) Vive la différence: Plant functional diversity matters to ecosystem processes. Trends in Ecology and Evolution 16: 646-655.

Dimitriadis C, Koutsoubas D (2011) Functional diversity and species turnover of benthic invertebrates along a local environmental gradient induced by an aquaculture unit: The contribution of species dispersal ability and rarity. Hydrobiologia 670: 307-315.

Dimitriou PD, Karakassis I, Pitta P, Tsagaraki TM, Apostolaki ET, Magiopoulos I et al. (2015) Mussel farming in Maliakos Gulf and quality indicators of the marine environment: Good benthic below poor pelagic ecological status. Marine Pollution Bulletin 101: 784-793.

Drouin A, Archambault P, Clynick B, Richer K, McKindsey CW (2015) Influence of mussel aquaculture on the distribution of vagile benthic macrofauna in Iles de la Madeleine, eastern Canada. Aquaculture Environment Interactions 6: 175-183.

Dubois S, Marin-Léal JC, Ropert M, Lefebvre S (2007) Effects of oyster farming on macrofaunal assemblages associated with Lanice conchilega tubeworm populations: A trophic analysis using natural stable isotopes. Aquaculture 271: 336-349.

Dumbauld BR, Ruesink JL, Rumrill SS (2009) The ecological role of bivalve shellfish aquaculture in the estuarine environment: A review with application to oyster and clam culture in West Coast (USA) estuaries. Aquaculture 290: 196-223.

Edebo L, Haamer J, Lindahl O, Lars-Ove L, Piriz L (2000) Recycling of macronutrients from sea to land using mussel cultivation. International Journal of Environment and Pollution 13: 190-207. Edwards P (2015) Aquaculture environment interactions: past, present and likely future trends. Aquaculture 447: 2-14.

Erler DV, Welsh DT, Bennet WW, Meziane T, Hubas C, Nizzoli D et al. (2017) The impact of suspended oyster farming on nitrogen cycling and nitrous oxide production in a sub-tropical Australian estuary. Estuarine, Coastal and Shelf Sciences 192: 117-127.

European Community (EC) (2000) Directive 200/60/EC of the European Parliament and of the Council of 23 October 2000 Establishing a Framework for Community Action in the Field of Water Policy.

Fabi G, Manoukian S, Spagnolo A (2009) Impact of an open-sea suspended mussel culture on macrobenthic community (Western Adriatic Sea). Aquaculture 289: 54-63.

Faulwetter S, Markantonatou V, Pavloudi C, Papageorgiou N, Keklikoglou K, Chatzinikolaou E et al. (2014) Polytraits: A database on biological traits of marine polychaetes. Biodiversity Data Journal 2: e1024.

Ferriss BE, Reum JC, McDonald PS, Farrell DM, Harvey CJ (2015) Evaluating trophic and nontrophic effects of shellfish aquaculture in a coastal estuarine foodweb. ICES Journal of Marine Science 73(2): 429-440.

Forrest BM, Keeley NB, Hopkins G, Webb S, Clement D (2009) Bivalve aquaculture in estuaries: Review and synthesis of oyster cultivation effects. Aquaculture 298: 1-15.

Fulford RS, Breitburg DL, Luckenbach M, Newell RIE (2010) Evaluating ecosystem response to 
oyster restoration and nutrient load reduction with a multispecies bioenergetics model. Ecological Applications 20: 915-934.

Gaertner-Mazouni N, Lacoste E, Bodoy A, Peacock L, Rodier M, Langlade MJ et al. (2012) Nutrient fluxes between water column and sediments: Potential influence of the pearl oyster culture. Marine Pollution Bulletin 65: 500-505.

Gagic V, Bartomeus I, Jonsson T, Taylor A, Winqvist C, Fischer C et al. (2015) Functional identity and diversity of animals predict ecosystem functioning better than species-based indices. Procedings of the Royal Society B: Biological Sciences 282: 20142620.

Gallardi D (2014) Effects of bivalve aquaculture on the environment and their possible mitigation: A review. Fisheries and Aquaculture Journal 5: 105.

Gamfeldt L, Lefcheck JS, Byrnes JEK, Cardinale BJ, Duffy JE, Griffin JN (2014) Marine biodiversity and ecosystem functioning: What's known and what's next? Oikos 124: 252-265.

Gerlotto F, Brehmer P, Buestel D, Sanguinède F (2001) A method for acoustic monitoring of a mussel longline ground using vertical echosounder and mutlibeam sonar. ICES Annual Science Conference Oslo, 26-29 Sept 2001:14 p.

Giles H, Broekhuizen N, Bryan KR, Pilditch CA (2009) Modelling the dispersal of biodeposits from mussel farms: The importance of simulating biodeposit erosion and decay. Aquaculture 291: 168-178.

Giles H, Pilditch CA (2006) Effects of mussel (Perna canaliculus) biodeposit decomposition on benthic respiration and nutrient fluxes. Marine Biology 150: 261-271

Giles H, Pilditch CA, Bell DG (2006) Sedimentation from mussel (Perna canaliculus) culture in the Firth of Thames, New Zealand: Impacts on sediment oxygen and nutrient fluxes. Aquaculture 261: $125-140$

Glud RN (2008) Oxygen dynamics of marine sediments. Marine Biology Research 4: 243-289.

Gosling SN (2013) The likelihood and potential impact of future change in the large-scale climateearth system on ecosystem services. Environmental Science Policy 27: S15-S31.

Grall J, Chauvaud L (2002) Marine eutrophication and benthos: The need for new approaches and concepts. Global Change Biology 8: 813-830.

Grant C, Archambault P, Olivier F, McKindsey CW (2012) Influence of "bouchot" mussel culture on the benthic environment in a dynamic intertidal system. Aquaculture Environment Interactions 2: 117-131.

Grant J, Hatcher A, Scott DB, Pocklington P, Schafer CT, Winters GV (1995) A multidisciplinary approach to evaluating impacts of shellfish aquaculture on benthic communities. Estuaries 18: 124-144.

Gutierrez JL, Jones CG, Strayer DL, Iribarne OO (2003) Mollusks as ecosystem engineers: the role of shell production in aquatic habitats. Oikos 101: 79-90.

Hargrave BT, Doucette LI, Cranford PJ, Law BA, Milligan TG (2008a) Influence of mussel aquaculture on sediment organic enrichment in a nutrient-rich coastal embayment. Marine Ecology Progress Series 365: 137-149.

Hargrave BT, Holmer M, Newcombe CP (2008b) Towards a classification of organic enrichment in 
marine sediments based on biogeochemical indicators. Marine Pollution Bulletin 56: 810-824. Hartstein ND, Rowden AA (2004) Effect of biodeposits from mussel culture on macroinvertebrate assemblages at sites of different hydrodynamic regime. Marine Environmental Research 57: 339-357.

Harvey E, Seguin A, Nozais C, Archambault P, Gravel D (2013) Identity effects dominate the impacts of multiple species extinctions on the functioning of complex food webs. Ecology $\mathbf{9 4}$ : $169-179$.

Hatcher A, Grant J, Schofield B (1994) Effects of suspended mussel culture (Mytilus spp.) on sedimentation, benthic respiration and sediment nutrient dynamics in a coastal bay. Marine Ecology Progress Series 115: 219-235.

Heilskov AC, Alperin M, Holmer M (2006) Benthic fauna bio-irrigation effects on nutrient regeneration in fish farm sediments. Journal of Experimental Marine Biology and Ecology 339: 204-225.

Hiddink JG, Wynter Davies T, Perkins M, Machairopoulou M, Neill SP (2009) Context dependency of relationships between biodiversity and ecosystem functioning is different for multiple ecosystem functions. Oikos 118: 1892-1900.

Holmer M, Thorsen SW, Carlsson MS, Kjerulf PJ (2015) Pelagic and benthic nutrient regeneration processes in mussel cultures (Mytilus edulis) in a eutrophic coastal area (Skive Fjord, Denmark). Estuaries and Coasts 38: 1629-1641

Hooper DU, Chapin FS, Ewel JJ, Hector A, Inchausti P, Lavorel S et al. (2005) Effects of biodiversity on ecosystem functioning: A consensus of current knowledge. Ecological Monographs 75: 3-35.

Hortal J, Bello F de, Diniz-Filho JAF, Lewinsohn TM, Lobo JM, Ladle RJ (2015) Seven shortfalls that beset large-scale knowledge of biodiversity. Annual Review of Ecology, Evolution and Systematics 46: 523-549.

Huang Q, Olenin S, Sun S, Troch M De (2018) Impact of farming non-indigenous scallop Argopecten irradians on benthic ecosystem functioning: A case-study in Laizhou Bay, China. Aquaculture Environment Interactions 10: 227-241.

Ieno EN, Solan M, Batty P, Pierce GJ (2006) How biodiversity affects ecosystem functioning: roles of inaunal species richness, identity and density in the marine benthos. Marine Ecology Progress Series 311: 263-271.

Isbell F, Calcagno V, Hector A, Connolly J, Harpole WS, Reich PB et al. (2011) High plant diversity is needed to maintain ecosystem services. Nature 477: 199-202.

Jacquet C, Moritz C, Morissette L, Legagneux P, Massol F, Archambault P et al. (2016) No complexity-stability relationship in empirical ecosystems. Nature Communications 7: 12573.

Jansen H, Strand Ø, Strohmeier T (2011) Seasonal variability in nutrient regeneration by mussel Mytilus edulis rope culture in oligotrophic systems. Marine Ecology Progress Series 431: $137-$ 149.

Kellogg ML, Smyth AR, Luckenbach MW, Carmichael RH, Brown BL, Cornwell JC et al. (2014) Use of oysters to mitigate eutrophication in coastal waters. Estuarine, Coastal and Shelf 
Sciences 151:156-168.

Kelly JP, Evens JG, Stallcup RW, Wimpfheimer D (1996) Effects of aquaculture on habitat use by wintering shorebirds in Tomales Bay, California. California Fish and Game 82: 160-174.

Kristensen E (1988) Benthic fauna and biogeochemical processes in marine sediments: Microbial activities and fluxes. In: Blackburn, T.H., Sørensen J (ed) Nitrogen Cycling in Costal Marine Environments. John Wiley \& Sons, Chrichester, p 301-341.

Kristensen E (2000) Organic matter diagenesis at the oxic/anoxic interface in coastal marine sediments, with emphasis on the role of burrowing animals. Hydrobiologia 426: 1-24.

Kristensen E, Delefosse M, Quintana CO, Flindt MR, Valdemarsen T (2014) Influence of benthic macrofauna community shifts on ecosystem functioning in shallow estuaries. Frontiers in Marine Science 1: 41.

Lacoste É, Drouin A, Weise AM, Archambault P, Mckindsey CW (2018a) Low benthic impact of an offshore mussel farm in Îles-de-la-Madeleine, eastern Canada. Aquaculture Environment Interactions 10: 473-485.

Lacoste E, Gaertner-Mazouni N (2015) Biofouling impact on production and ecosystem functioning: A review for bivalve aquaculture. Reviews in Aquaculture 7: 187-196.

Lacoste É, Gaertner-Mazouni N (2016) Nutrient regeneration in the water column and at the sediment-water interface in pearl oyster culture (Pinctada margaritifera) in a deep atoll lagoon (Ahe, French Polynesia). Estuarine Coastal and Shelf Sciences 182: 304-309.

Lacoste E, Gueguen Y, Le Moullac G, Koua MS, Gaertner-Mazouni N (2014) Influence of farmed pearl oysters and associated biofouling communities on nutrient regeneration in lagoons of French Polynesia. Aquaculture Environment Interactions 5: 209-219.

Lacoste É, Piot A, Archambault P, McKindsey CW, Nozais C (2018b) Bioturbation activity of three macrofaunal species and the presence of meiofauna affect the abundance and composition of benthic bacterial communities. Marine Environmental Research 136: 62-70.

Lacoste É, Weise AM, Lavoie M, Archambault P, McKindsey CW (2019) Changes in infaunal assemblage structure influence nutrient fluxes in sediment enriched by mussel biodeposition. Science of the Total Environment 692: 39-48.

Laliberté E, Legendre P (2010) A distance-based framework for measuring functional diversity from multiple traits. Ecology 91: 299-305.

Mahmoudi E, Hedfi A, Essid N, Beyrem H, Aïssa P, Boufahja F et al. (2008) Mussel-farming effects on Mediterranean benthic nematode communities. Nematology 10: 323-333.

Mallet A, Carver C, Landry T (2006) Impact of suspended and off-bottom Eastern oyster culture on the benthic environment in eastern Canada. Aquaculture 255: 362-373.

Marchini A, Munari C, Mistri M (2008) Functions and ecological status of eight Italian lagoons examined using biological traits analysis (BTA). Marine Pollution Bulletin 56: 1076-1085.

Martinez-Garcia E, Carlsson MS, Sanchez-Jerez P, Sánchez-Lizaso JL, Sanz-Lazaro C, Holmer M (2015) Effect of sediment grain size and bioturbation on decomposition of organic matter from aquaculture. Biogeochemistry 125: 133-148.

Mazouni N (2004) Influence of suspended oyster cultures on nitrogen regeneration in a coastal 

lagoon (Thau, France). Marine Ecology Progress Series 276: 103-113.

Mazouni N, Gaertner JC, Deslous-Paoli JM (2001) Composition of biofouling communities on suspended oyster cultures: an in situ study of their interactions with the water column. Marine Ecology Progress Series 214: 93-102.

Mazouni N, Gaertner JC, Deslous-Paoli JM, Landrein S, Geringer D’Oedenberg M (1996) Nutrient and oxygen exchanges at the water-sediment interface in a shellfish farming lagoon (Thau, France). Journal of Experimental Marine Biology and Ecology 205: 91-113.

Mckindsey CW, Archambault P, Callier MD, Olivier F (2011) Influence of suspended and offbottom mussel culture on the sea bottom and benthic habitats: a review. Canadian Journal of Zoology 89: 622-646.

McKindsey CW, Archambault P, Simard N (2012) Spatial variation of benthic infaunal communities in baie de Gaspé (eastern Canada) - Influence of mussel aquaculture. Aquaculture 356: 48-54.

McKindsey CW, Lecuona M, Huot M, Weise AM (2009) Biodeposit production and benthic loading by farmed mussels and associated tunicate epifauna in Prince Edward Island. Aquaculture 295: 44-51.

Miron G, Landry T, MacNair NG (2002) Predation potential by various epibenthic organisms on commercial bivalve species in Prince Edward Island: Preliminary results. Canadian Technical Report of Fisheries and Aquatic Science 2392: 44.

Miron G, Landry T, Archambault P, Frenette B (2005) Effects of mussel culture husbandry practices on various benthic characteristics. Aquaculture 250: 138-154.

Mirto S, La Rosa T, Danovaro R, Mazzola A (2000) Microbial and meiofaunal response to intensive mussel-farm biodeposition in coastal sediments of the western Mediterranean. Marine Pollution Bulletin 40: 244-252.

Mouchet MA, Villéger S, Mason NWH, Mouillot D (2010) Functional diversity measures: an overview of their redundancy and their ability to discriminate community assembly rules. Functional Ecology 24: 867-876.

Mouillot D, Graham NAJ, Villéger S, Mason NW, Bellwood DR (2013) A functional approach reveals community responses to disturbances. Trends in Ecology and Evolution 28: 167-177.

Mouillot D, Spatharis S, Reizopoulou S, Laugier T, Sabetta L, Basset A et al. (2006) Alternatives to taxonomic-based approaches to assess changes in transitional water communities. Aquatic Conservation in Marine and Freshwater Ecosystems 16: 469-482.

Mouillot D, Villeger S, Scherer-Lorenzen M, Mason NW (2011) Functional structure of biological communities predicts ecosystem multifunctionality. PLoS One 6(3): e17476.

Murphy AE, Anderson IC, Smyth AR, Song B, Luckenbach MW (2016) Microbial nitrogen processing in hard clam (Mercenaria mercenaria) aquaculture sediments: the relative importance of denitrification and dissimilatory nitrate reduction to ammonium (DNRA). Limnology and Oceanography 61: 1589-1604.

Newell RIE (2004) Ecosystem influences of natural and cultivated populations of suspensionfeeding bivalve molluscs: a review. Journal of Shellfish Research 23: 15-61.

Nizzoli D, Welsh DT, Bartoli M, Viaroli P (2005) Impacts of mussel (Mytilus galloprovincialis) 
farming on oxygen consumption and nutrient recycling in a eutrophic coastal lagoon. Hydrobiologia 550: 183-198

Nizzoli D, Welsh DT, Fano EA, Viaroli P (2006) Impact of clam and mussel farming on benthic metabolism and nitrogen cycling, with emphasis on nitrate reduction pathways. Marine Ecology Progress Series 315: 151-165.

Nizzoli D, Welsh D, Viaroli P (2011) Seasonal nitrogen and phosphorus dynamics during benthic clam and suspended mussel cultivation. Marine Pollution Bulletin 62: 1276-87.

O’Connor NE, Crowe TP (2005) Biodiversity loss and ecosystem functioning: Distinguishing between number and identity of species. Ecology 86: 1783-1796.

Oliver TH, Heard MS, Isaac NJB, Roy DB, Procter D, Eigenbrod F et al. (2015) Biodiversity and resilience of ecosystem functions. Trends in Ecology and Evolution 30: 673-684.

Pauly D, Christensen V, Dalsgaard J, Froese R, Torres F (1998) Fishing down marine food webs. Science 279(5352): 860-863.

Pearson TH, Rosenberg R (1978) Macrobenthic succession in relation to organic enrichment and pollution of the marine environment. Oceanography and Marine Biology: An Annual Review 16: 229-311.

Piot A, Nozais C, Archambault P (2014) Meiofauna affect the macrobenthic biodiversity-ecosystem functioning relationship. Oikos 123: 203-213.

Politi T, Zilius M, Castaldelli G, Bartoli M, Daunys D (2019) Estuarine macrofauna affects benthic biogeochemistry in a hypertrophic lagoon. Water 11(6): 1186

Pollet T, Cloutier O, Nozais C, McKindsey CW, Archambault P (2015) Metabolic activity and functional diversity changes in sediment prokaryotic communities organically enriched with mussel biodeposits. PLoS One 10: e123681 .

Pombo A, Baptista T, Granada L, Ferreira SM, Gonçalves SC, Anjos C et al. (2018) Insight into aquaculture's potential of marine annelid worms and ecological concerns: a review. Reviews in Aquaculture 1-15. doi: 10.1111/raq.12307.

Pomeroy LR, D’Elia CF, Schaffner LC (2006) Limits to top-down control of phytoplankton by oysters in Chesapeake Bay. Marine Ecology Progress Series 325: 301-309.

Price C, Black KD, Hargrave BT, Morris JA Jr (2015) Marine cage culture and the environment: effects on water quality and primary production. Aquaculture Environment Interactions 6: 151174.

Prins T, Smaal A, Dame R (1998) A review of the feedbacks between bivalve grazing and ecosystem processes. Aquatic Ecology 31: 349-359.

Richard M, Archambault P, Thouzeau G, Desrosiers G (2006) Influence of suspended mussel lines on the biogeochemical fluxes in adjacent water in the Îles-de-la-Madeleine (Quebec, Canada). Canadian Journal of Fisheries and Aquatic Sciences 63: 1198-1213.

Richard M, Archambault P, Thouzeau G, McKindsey C, Desrosiers G (2007a) Influence of suspended scallop cages and mussel lines on pelagic and benthic biogeochemical fluxes in Havre-aux-Maisons Lagoon, Îles-de-la-Madeleine (Quebec). Canadian Journal of Fisheries and Aquatic Sciences: 64(11): 1491-1505.

Richard M, Archambault P, Thouzeau G, Desrosiers G (2007b) Summer influence of 1 and 2 yr old 
mussel cultures on benthic fluxes in Grande-Entrée lagoon, Îles-de-la-Madeleine (Québec, Canada). Marine Ecology Progress Series 338: 131-143.

Robert P, Mckindsey C, Chaillou G, Archambault P (2013) Dose-dependent response of a benthic system to biodeposition from suspended blue mussel (Mytilus edulis) culture. Marine Pollution Bulletin 66: 92-104.

Rose JM, Bricker SB, Tedesco MA, Wikfors GH (2014) A role for shellfish aquaculture in coastal nitrogen management. Environmental Science and Technology 48: 2519-2525.

Sardenne F, Forget N, McKindsey CW (2019) Contribution of mussel fall-off from aquaculture to wild lobster Homarus americanus diets. Marine Environmental Research 149: 126-136.

Schratzberger M, Ingels J (2017) Meiofauna matters: The roles of meiofauna in benthic ecosystems. Journal of Experimental Marine Biology and Ecology 502: 12-25.

Séguin A, Harvey É, Archambault P, Nozais C, Gravel D (2014) Body size as a predictor of species loss effect on ecosystem functioning. Scientific Report 4: 4616.

Slater MJ, Carton AG (2009) Effect of sea cucumber (Australostichopus mollis) grazing on coastal sediments impacted by mussel farm deposition. Marine Pollution Bulletin 58: 1123-1129.

Slater MJ, Carton AG (2010) Sea cucumber habitat differentiation and site retention as determined by intraspecific stable isotope variation. Aquaculture Research 41(10): 695-702.

Smyth AR, Geraldi NR, Piehler MF (2013) Oyster-mediated benthic-pelagic coupling modifies nitrogen pools and processes. Marine Ecology Progress Series 493: 23-30.

Snelgrove PVR (1998) The biodiversity of macrofaunal organisms in marine sediments. Biodiversity Conservation 7: 1123-1132.

Snelgrove PVR, Thrush SF, Wall DH, Norkko A (2014) Real world biodiversity-ecosystem functioning: A seafloor perspective. Trends in Ecology and Evolution 29: 398-405.

Solan M, Aspden R, Paterson D (Eds) (2012) Marine biodiversity and ecosystem functioning: frameworks, methodologies, and integration. Oxford University Press, Oxford.

Solan M, Cardinale BJ, Downing AL, Engelhardt KAM, Ruesink JL, Srivastava DS (2004) Extinction and ecosystem function in the marine benthos. Science 306: 1177-1180.

Soto D, Aguilar-Manjarrez J, Brugère C, Angel D, Bailey C, Black K et al. (2008) Applying an ecosystem-based approach to aquaculture: principles, scales and some management measures. Building an Ecosystem Approach to Aquaculture. FAO/Universitat les Illes Balear Expert Work 7-11 May 2007, Palma Mallorca, Spain FAO Fisheries and Aquaculture Proceedings 14: $15-35$.

Stenton-Dozey J, Probyn T, Busby A (2001) Impact of mussel (Mytilus galloprovincialis) raftculture on benthic macrofauna, in situ oxygen uptake, and nutrient fluxes in Saldanha Bay, South Africa. Canadian Journal of Fisheries and Aquatic Sciences 58: 1021-1031.

Strong JA, Andonegi E, Bizsel KC, Danovaro R, Elliott M, Franco A et al. (2015) Marine biodiversity and ecosystem function relationships: The potential for practical monitoring applications. Estuarine, Coastal and Shelf Sciences 161: 46-64.

Theodorou JA, James R, Tzovenis I, Hellio C (2015) The Recruitment of the endangered fan mussel 
Pinna nobilis (Linnaeus, 1758) on the ropes of a mediterranean mussel long line farm. Journal of Shellfish Research 34: 409-414.

Thouzeau G, Grall J, Clavier J, Chauvaud L, Jean F, Leynaert A et al. (2007) Spatial and temporal variability of benthic biogeochemical fluxes associated with macrophytic and macrofaunal distributions in the Thau lagoon (France). Estuarine, Coastal and Shelf Sciences 72: 432-446.

Valenti WC, Kimpara JM, Preto B de L, Moraes-Valenti P (2018) Indicators of sustainability to assess aquaculture systems. Ecological Indicators 88: 402-413.

Villéger S, Mason NWH, Mouillot D (2008) New multidimensional functional diversity indices for a multifaceted framework in functional ecology. Ecology 89: 2290-2301.

Waldbusser GG, Marinelli RL (2006) Macrofaunal modification of porewater advection: Role of species function, species interaction, and kinetics. Marine Ecology Progress Series 311: $217-$ 231

Walker BH (1992) Biodiversity and Ecological Redundancy. Conservation Biology 6: 18-23.

Weise AM, Cromey CJ, Callier MD, Archambault P, Chamberlain J, McKindsey CW (2009) Shellfish-DEPOMOD: Modelling the biodeposition from suspended shellfish aquaculture and assessing benthic effects. Aquaculture 288: 239-253.

Welsh DT (2003) It's a dirty job but someone has to do it: The role of marine benthic macrofauna in organic matter turnover and nutrient recycling to the water column. Chemical Ecology 19: 321-342.

White CA, Nichols PD, Ross DJ, Dempster T (2017) Dispersal and assimilation of an aquaculture waste subsidy in a low productivity coastal environment. Marine Pollution Bulletin 120: 309 321.

Wilding TA, Nickell TD (2013) Changes in benthos associated with mussel (Mytilus edulis L.) farms on the West-Coast of Scotland. PLoS One 8: e68313.

Wong KLC, O'Shea S (2011) The effects of a mussel farm on benthic macrofaunal communities in Hauraki Gulf, New Zealand. New Zealand Journal of Marine and Freshwater Research 45: $37-$ 41.

Woodcock SH, Strohmeier T, Strand, Olsen SA, Bannister RJ (2018) Mobile epibenthic fauna consume organic waste from coastal fin-fish aquaculture. Marine Environmental Research 137: $16-23$.

Woods CMC, Floerl O, Hayden BJ (2012) Biofouling on Greenshellтm mussel (Perna canaliculus) farms: a preliminary assessment and potential implications for sustainable aquaculture practices. Aquaculture International 20: 537-557.

Word JQ (1979) The infaunal trophic index. In: Bascom W (Ed) Southern California Coastal Water Research Project, Annual Report (1979). SCCWRP, Los Angeles, p 19-39 .

Wrede A, Dannheim J, Gutow L, Brey T (2017) Who really matters: Influence of German Bight key bioturbators on biogeochemical cycling and sediment turnover. Journal of Experimental Marine Biology and Ecology 488: 92-101.

Würsig B, Gailey GA (2002) Marine mammals and aquaculture: conflicts and potential resolutions. In: Stickney R, McVey J (Eds) Responsible marine aquaculture, CABI Publishing, Oxon, p 45- 
900

901

902

903

904

905

906

907

59.

Zeppilli D, Sarrazin J, Leduc D, Arbizu PM, Fontaneto D, Fontanier C et al. (2015) Is the meiofauna a good indicator for climate change and anthropogenic impacts? Marine Biodiversity 45: 505535.

Zúñiga D, Castro CG, Aguiar E, Labarta U, Figueiras FG, Fernández-Reiriz MJ (2014) Biodeposit contribution to natural sedimentation in a suspended Mytilus galloprovincialis Lmk mussel farm in a Galician Ria (NW Iberian Peninsula). Aquaculture 432: 311-320. 